\title{
FLOTATION CIRCUIT PERFORMANCE DETERMINATION USING SIZE BY SIZE RECOVERY - CASE OF BULYANHULU GOLD MINE
}

\author{
Savinus J. Maronga and Faustine Ngoroma \\ Department of Chemical and Mining Engineering, University of Dar-es- \\ Salaam, \\ P.O. Box 35131, Dar-es-Salaam, Tanzania \\ Tel: [+255] 222410268 e-mail: smaronga@udsm.ac.tz
}

\begin{abstract}
The Bulyanhulu rougher flotation circuit performance has been determined by establishing the performance of individual cells. Direct sampling was done on all the rougher cell input, output and size analysis was performed on the samples with material in each size fraction assayed for copper and gold to determine their recoveries. It was observed that the performance of rougher cell number 3 and 4 was poor compared to other cells especially for finer particles below $53 \mu \mathrm{m}$ where the recoveries were below $60 \%$. In the last two flotation cells recoveries of both metals was very good (above 90\%) in all particle sizes. The comminution circuit designated of $80 \%$ passing of $75 \mu \mathrm{m}$ is still valid since in the last three cells, a good recovery of between 72 and $97 \%$ was obtained for both gold and copper in the +53-106 $\mu \mathrm{m}$ size range. Over grinding of the ore to below $53 \mu \mathrm{m}$ should be minimized since the very fine sizes yield poor recovery of both gold and copper in all cells.
\end{abstract}

Keywords: Size-by-size recovery, Flotation efficiency, Rougher performance

\section{INTRODUCTION}

At Bulyanhulu Gold Mine, gold occurs in the ore in a variety of forms including: liberated gold; liberated electrum which is a mixture of gold and silver; and gold and electrum locked inside or attached to sulphide minerals. The sulphide minerals mined at Bulyanhulu are mainly pyrite $\left(\mathrm{FeS}_{2}\right)$ and chalcopyrite $\left(\mathrm{CuFeS}_{2}\right)$. The ore being fed to the processing plant contains an approximate of 12 to $14 \mathrm{~g} / \mathrm{t}$ gold and $0.5 \%$ copper.

The metallurgical process employed at Bulyanhulu consist of grinding, gravity concentration, flotation and CIL cyanide recovery. The process plant is designed to recover the different forms of gold using three different methods namely: gravity method in which liberated gold and electrum particles are recovered using gravity techniques to produce dore bars; flotation method where gold and electrum contained in sulphide minerals are to produce a copper concentrate; and CIL cyanide process where gold is leached using cyanide and latter recovered by electrowining and produce dore bars. Approximately $60 \%$ of the gold produced at Bulyanhulu is recovered as copper concentrate containing approximately 250 $\mathrm{g} / \mathrm{t}$ gold, $200 \mathrm{~g} / \mathrm{t}$ silver and $16 \%$ copper. Since extraction of gold, silver and copper from concentrate requires highly specialized secondary processing and refining, at present the copper concentrate is shipped to overseas smelters for final metal extraction.

The Bulyanhulu flotation circuit was modified and as a result its performance has changed over time. At the time of this study, gold recovery was $87.92 \%$ while expected value was $89.15 \%$ and the actual concentrate grade was $13.4 \% \mathrm{Cu}$ compared to designed value of $15 \% \mathrm{Cu}$. The recovery of copper, gold and silver has decreased. The rougher cells performance is mainly influenced by: agitation rate; amount and point addition of reagent; pulp temperature; and particle 
size distribution of the rougher feed. It was therefore, necessary to establish the performance in the rougher circuit by determining size-by-size recovery of each cell.

\section{Mechanisms of Flotation}

The flotation process is usually used for the separation of large range of sulphide, carbonates and oxides ores prior to further refinement. A flotation system consists of three different phases represented by water, air, and solid particles. In the flotation cells, agitators or impellers maintain the fine-grained solids in suspension while a continuous stream of air bubbles rises from the bottom to the top of the cell. For mineral separation to take palace, certain particles attach themselves to the bubbles, which take them to the surface. These bubbles have to form a froth stable enough to carry the floated mineral particles until they are removed from the top of the cell (Crozer, 1963; Afrane et al, 2001).

In order for the floated particles to defy the gravity, they must not exceed certain dimensions, depending on the their specific gravity. Froth flotation is therefore preceded by comminution, the process in which rocks are broken and grounded to a fine powder. The upper limit particle size rarely exceeds 500 microns and is usually below 300 micron but optimum results are generally obtained with particle sizes ranging from 10 to 100 microns. Particles below 10 microns have a tendency to form slimes which negatively affect flotation process (Wills, 1997).

Flotation is a selective process of separating mineral from gangue by utilizing differences in physical-chemical surface properties of particle of various minerals. The flotation efficiency of mineral enrichment is much influenced by the surface properties of the minerals.
The floatability of a mineral depends on its ability to adhere to air bubbles and the bubbles can only stick to the mineral particles if they can displace water from the particle surface. In reaching that goal, particle surface properties can be modified by the use of suitable chemical reagents. Particles that get readily attached to air bubbles are water are hydrophobic; those that do not are hydrophilic. Polar minerals such as sulphides have to be conditioned by chemical reagents, commonly known as collectors, before they can be recovered by flotation. The choice of particular chemical depends on the ore being refined, for example in extract copper, pine oil which is used. Some of the reagents like collectors are added to the pulp in special conditioning tanks while others are added on the flotation cells. Frothers are added to create persistent bubbles which forms a stable froth that carry the load of floated minerals to the top of the flotation cell. The foam is removed and the concentrated mineral is further refined (Personage, 1985; Sotherland, 1955; Bolatovic, 2007; Gaudin, 1957 ).

One can determine the state of a flotation process by anaysing the form of the froth layer on the top of the flotation cell. Since mineral composition tend to vary even within the same mine, the operators of flotation process usually use the visual appearance of the froth layer including colour, speed and shape to determine the suitable levels of the reagents to be added to a specific batch of the ore (Basilevsky, 1994; Fuerstenau and Han, 2003).

\section{Bulyanhulu Flotation Circuit}

Before feeding into the flotation plant the ore must first be prepared for suitable recovery. The ore is mined underground, transported to the surface and dumped on the crusher pad. A loader feeds the ore to the jaw crusher, which reduces the rocks 
from about $600 \mathrm{~mm}$ to less than $120 \mathrm{~mm}$. Crushed ore is conveyed to a semi autogenous grinding (SAG) mill where water is added to form slurry. The SAG mill has $100 \mathrm{~mm}$ steel balls grind the ore from $120 \mathrm{~mm}$ to less than $6 \mathrm{~mm}$. The -6 $\mathrm{mm}$ particles pass through a screen while the oversize particles are recycled for further grinding.

Particles that pass through the screen has their pulp density adjusted to $62 \%$ solids and are then pumped to the primary cyclone classifiers where fine particles are separated from coarse particles. The fine particles, $75 \%$ of which of these are less than $75 \mu \mathrm{m}$, are sent to the flotation process while the coarse particle stream is divided into two streams, one part is fed to the gravity circuit and the other stream recycled back to the ball mill for further grinding.

The feed to the flotation plant is passed through the conditioning tank where reagents are added and the mixture is agitated to achieve emulsification. The pulp and

reagents are fed down the open standpipe and fall on the propeller, which forces the mixture downwards, and outward. The outlet of the side of the tank can be adjusted to give the pulp sufficient height for a desired resident time in the tank. Bulyanhulu process use potassium amyl xantate (PAX) as primary collector, carboxyl methyl cellulose (CMC) as secondary collector; methyl isobutyl carbinol (MIBC) and Dow Froth 200 as frothers; and lime as $\mathrm{pH}$ control. Table 1 shows the dosage for each reagent and points at which they are added to the process. Rougher feed from the conditioning tank enters the first cell of rougher bank in which sulphide minerals are collected. Air is injected and bubbles rise to the surface in a froth, carrying with it the valuable sulphide minerals on their surface. The froth overflows the cells and rougher concentrate is collected. The slurry that is not collected as froth in the first cell flows to the second cell where more of the mineralized froth is removed. The slurry continues to the third cell and so on until barren tailing overflows the last cell in the bank. The slurry that is not collected as froth in the last cell becomes material called rougher tails which is sent to the CIL plant for further gold recovery. The rougher concentrate is classified, sent to the re-grind mill and then to the cleaner flotation circuit to produce the final copper-concentrate.

Table 1: Reagents and Points of Addition Used by Bulyanhulu Process Plant

\begin{tabular}{|l|l|l|l|}
\hline Reagent & Function & $\begin{array}{l}\text { Amount added } \\
\mathbf{( k g / t )}\end{array}$ & Addition Point \\
\hline PAX & $\begin{array}{l}\text { Primary } \\
\text { Collector }\end{array}$ & 0.145 & $\begin{array}{l}\text { Every rougher } \\
\text { cell except cell } 2\end{array}$ \\
\hline CMC & Collector & 0.044 & $\begin{array}{l}\text { Contact cell } \\
\text { Rougher condition tank } \\
\text { Cleaner 1 condition tank. }\end{array}$ \\
\hline Dow Froth & Frother & 0.025 & $\begin{array}{l}\text { All roughers } \\
\text { All cleaner cells }\end{array}$ \\
\hline MIBC & Frother & 0.012 & $\begin{array}{l}\text { All roughers } \\
\text { All cleaner cells }\end{array}$ \\
\hline Lime & pH Modifier & 0.821 & Mill feed conveyor \\
\hline
\end{tabular}




\section{METHODOLOGY}

The study was carried out at the Bulyanhulu process plant focusing on the rougher flotation circuit. The process has seven rougher cells with roughers 2 and 3; and roughers 4 and 5 being 'coupled' i.e. no interconnecting pipe between these adjacent cells and slurry was allowed to flow between the two. To establish the recoveries representative slurry samples was collected from the rougher circuit in the process plant. The samples were then analysed for copper and gold contents. Due to the rougher circuit design, a total of 12 points were identified for sampling points. Twelve containers of 4 liters each were prepared and samples were collected from the following points as shown in Figure 1;

1. Rougher feed from the primary cyclone overflow

2. Rougher 1 concentrate

3. Rougher 1 tailings

4. Rougher 2 concentrate

5. Rougher 3 concentrate

6. Rougher 3 tailings

7. Rougher 4 concentrate

8. Rougher 5 concentrate

9. Rougher 5 tailings

10. Rougher 6 concentrate

11. Rougher 7 concentrate

12. Rougher 7 tailings

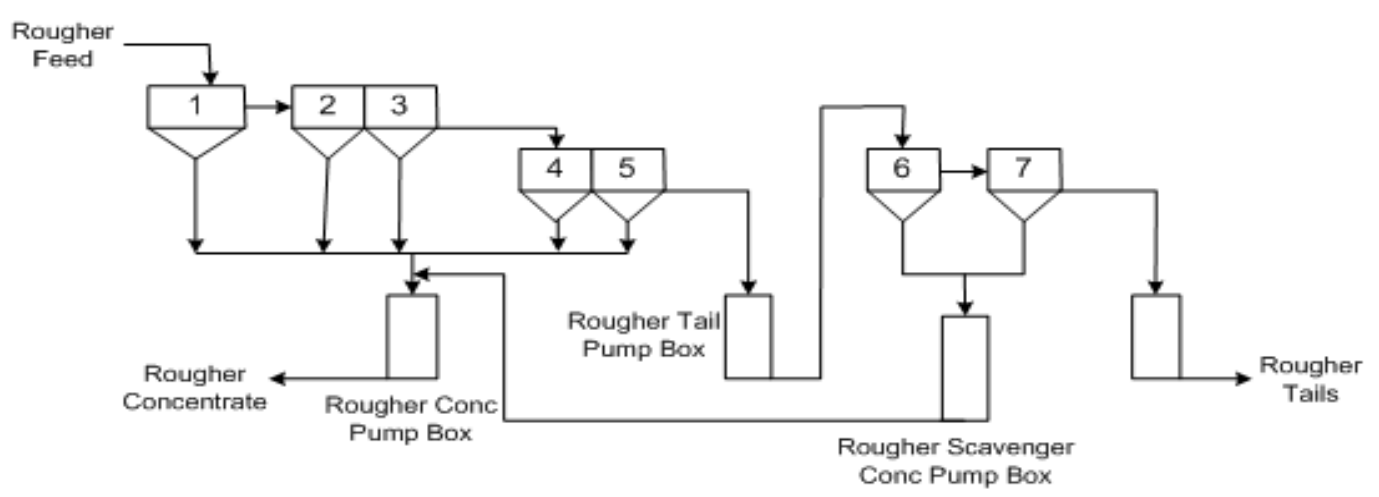

Figure 1: Bulyanhulu Rougher Flotation Circuit

Collected samples were weighed, filtered and dried in oven at $120^{\circ} \mathrm{C}$ for 12 hours. The dry samples were weighed to establish percentage solids. The samples were homogenized and riffle splited to obtain a representative sample of each. Wet sieving was performed to obtain +38 microns and -38 microns fractions. Both fraction were then dried on the oven for 12 hours at $120{ }^{\circ} \mathrm{C}$ and weighed. The sieve analysis performed for the $+38 \mu \mathrm{m}$ fraction and cyclosizing for $-38 \mu \mathrm{m}$ fraction. Samples from each fraction was taken to the assay laboratory determine the gold and copper analysis. Then recovery for every size in each cell was calculated using the two-product formula:

$$
R=\frac{c(f-t)}{f(c-t)} 100 \%
$$

where $c, f$, and $t$ are concentrate, feed and tailings assays respectively.

\section{DISCUSSION OF THE RESULTS}

Recoveries of both gold and copper for different particle sizes in all rougher cells were determined. The results for both copper and gold were plotted in the same graphs to allow for easy comparison to be made. This can easily show the presence of segregation error which sometimes is associated with the gold sampling (Mular et al, 2002). 
Copper recoveries in rougher cell number 1 was found to be higher in the size range between $38 \mu \mathrm{m}$ and $75 \mu \mathrm{m}$ where about $90 \%$ of the copper was recovered (Figure $2)$. Recovery of copper decreases with the increase in particles size for the $+75 \mu \mathrm{m}$, declining to just $20 \%$ for $212 \mu \mathrm{m}$ size. In the first rougher cell, the recovery of gold fluctuates between low $20 \%$ and mid $50 \%$ in almost all particle size ranges. The exceptional for the gold, are the finest particles $(-8.4 \mu \mathrm{m})$ whose recoveries were about

$72 \%$.

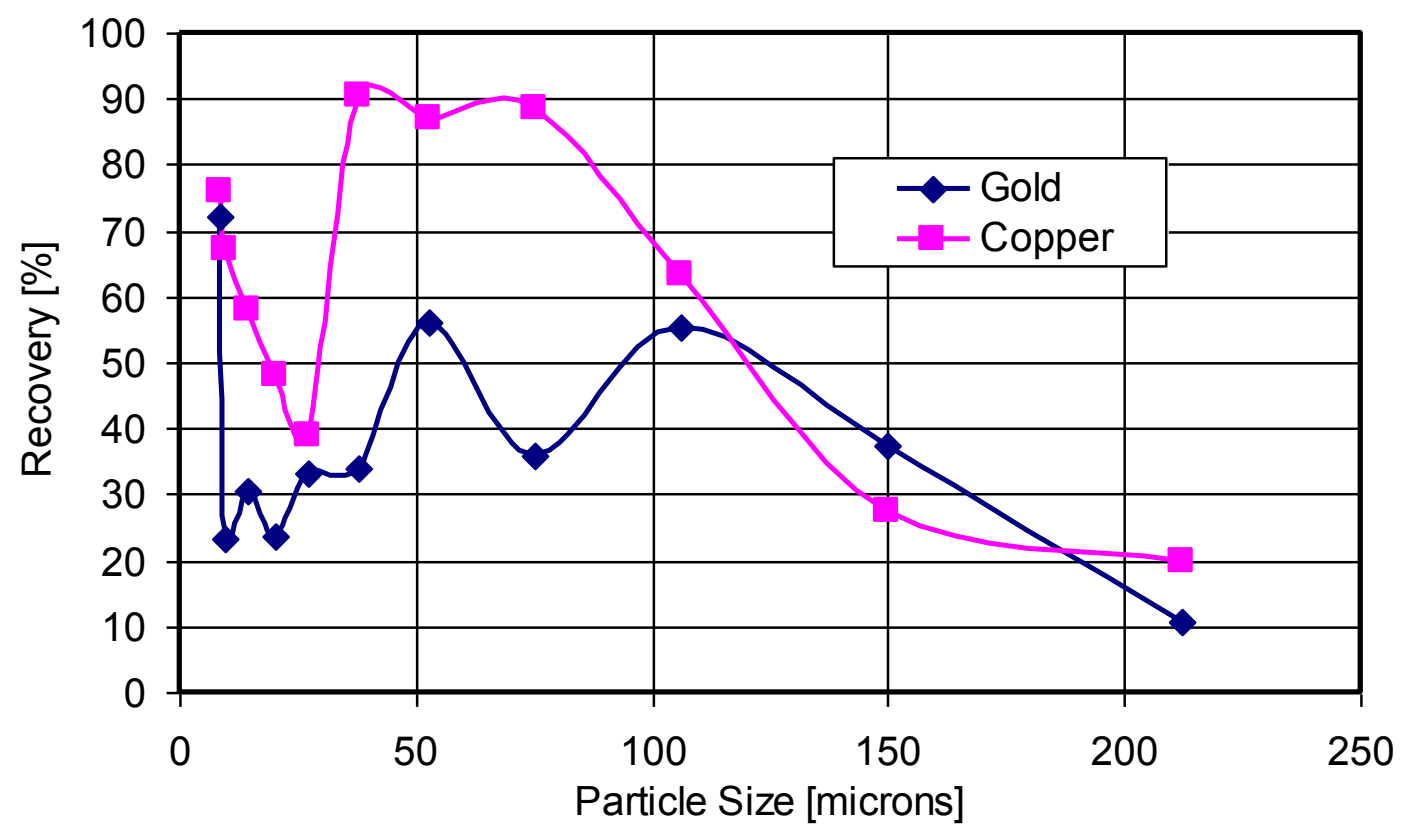

Figure 2: Gold and Copper Recovery for Rougher Cell Number 1

In rougher cells 2 and 3 there is a similar trend in gold recovery to that found in the first cell but with slightly better recovery for the finer particles $(-9.7 \mu \mathrm{m})$, decreasing to a minimum for the $20 \mu \mathrm{m}$ particle size and then increase in recovery for the $+38-75 \mu \mathrm{m}$ size range. Compared to cell 1, however, there is an improvement of recovery for the coarse particles $(+120 \mu \mathrm{m})$ as solution moves through rougher cells 2 and 3 . Overall the gold recovery in cell 2 equals or is better than that of cell 3 in all particle sizes. Investigators of this work could not find apparent explanations to this behavior.
Copper recoveries in cells 2 and 3 are high in very fine particles sizes then decrease with the increase in particle size reaching a minimum recovery at particle size $27.1 \mu \mathrm{m}$, before increasing with the increase of particle sizes. The big difference between copper and gold recoveries for the coarse particles seen in Figures 3 and 4 can be attributed to the difference in specific gravity between the two with the coarse gold particles too heavy to be easily carried up by the bubbles (Wills, 1997). 


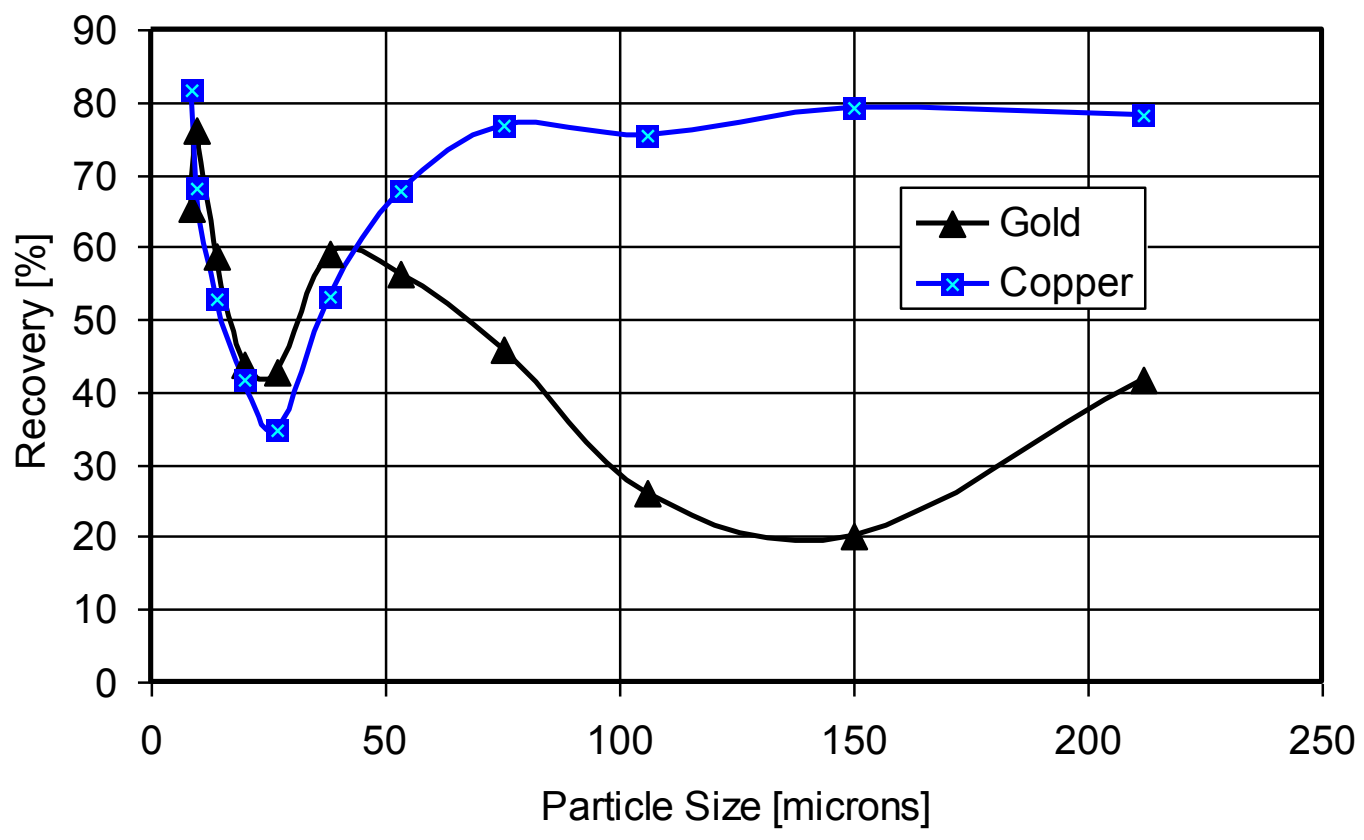

Figure 3: Gold and Copper Recovery for Rougher Cell Number 2

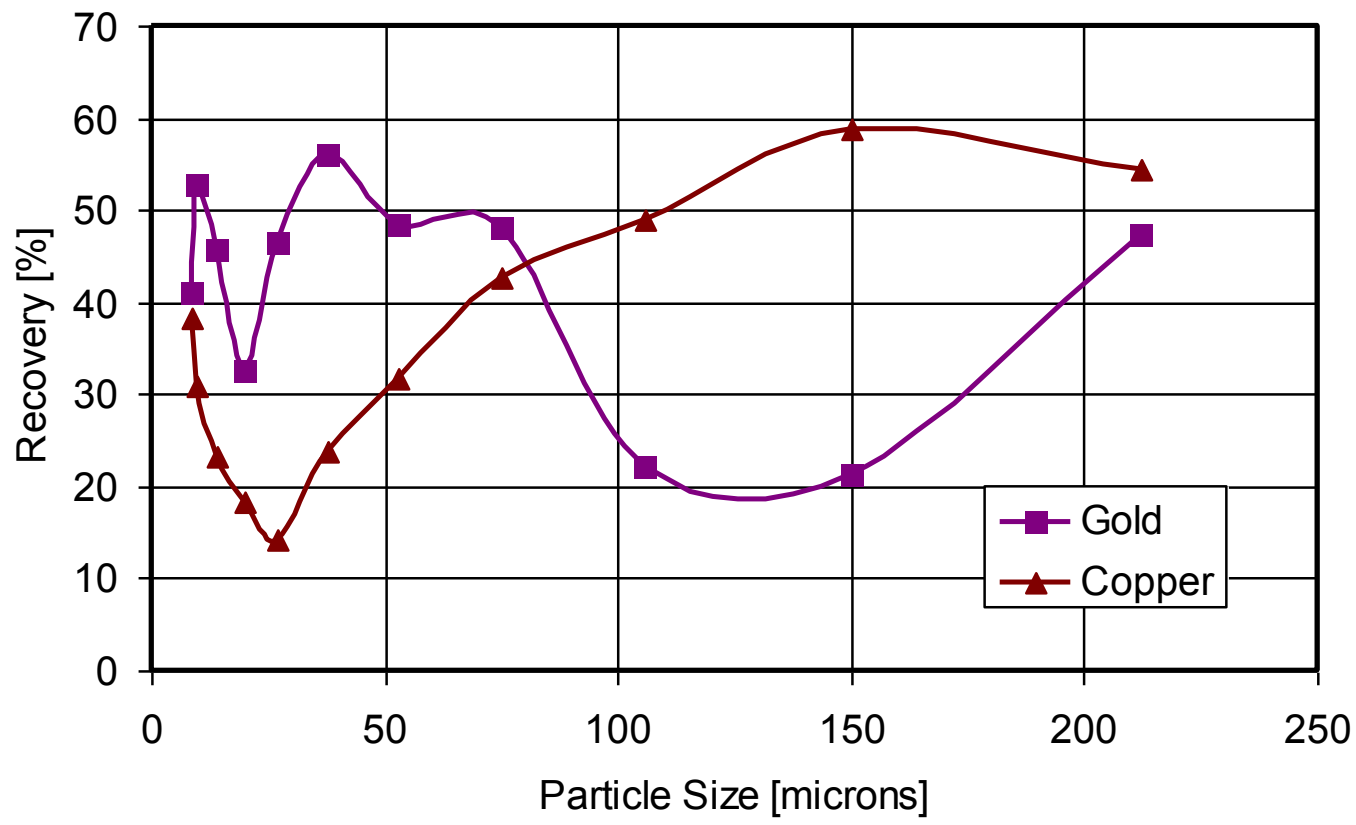

Figure 4: Gold and Copper Recovery for Rougher Cell Number 3

Figure 5 shows lower recoveries below $40 \%$ in rougher cell number 4 for both copper and gold in the fine size fractions $(-53 \mu \mathrm{m})$. It increases in the size above $53 \mu \mathrm{m}$ up to $80 \%$ and $78 \%$ for copper and gold respectively. Although the recovery trend for the two metals in cell 4 is very similar, the copper recoveries were higher than gold recoveries in all particle sizes. This could also be attributed to the difference in specific gravity of the two metals. 


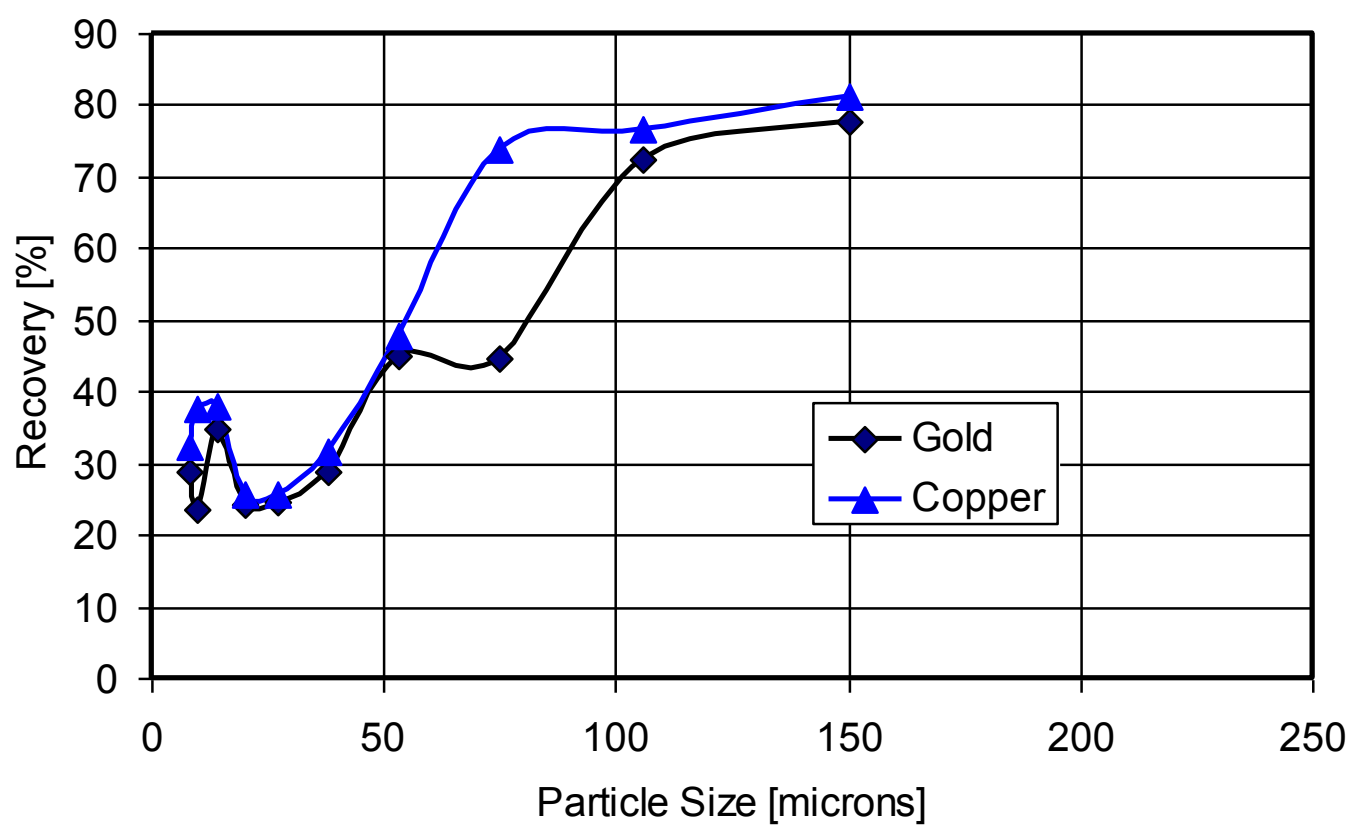

\section{Figure 5: Gold and Copper Recovery for Rougher Cell Number 4}

In rougher cell 5 which is coupled with cell 4, again the gold and copper recovery show the same trend with higher recoveries at the very fine particle sizes ($14.2 \mu \mathrm{m})$, poor recoveries in fine particle sizes $(+20$ to $-38 \mu \mathrm{m})$ and very good recovery for coarse sizes $(+53 \mu \mathrm{m})$. In very coarse particles $(+150 \mu \mathrm{m})$ the recovery tend to decrease again.

In the last two rougher cells 6 and 7, the recovery trends of gold and that of copper are very similar. In the finer particle sizes, copper recovery is better than gold recovery, whereas as the particle size increases the gold is marginally better recovered as compared to copper as shown in Figures 7 and 8. For cell 6, the best gold is recovered is obtained for particle range +53 to $-150 \mu \mathrm{m}$ and for cell 7 for +27.1 to $-75 \mu \mathrm{m}$ size range. In both cells, the recovery decreases as particle size increases to the coarse size range, reaching $44 \%$ and $40 \%$ for gold and copper respectively for the $150 \mu \mathrm{m}$ size. 


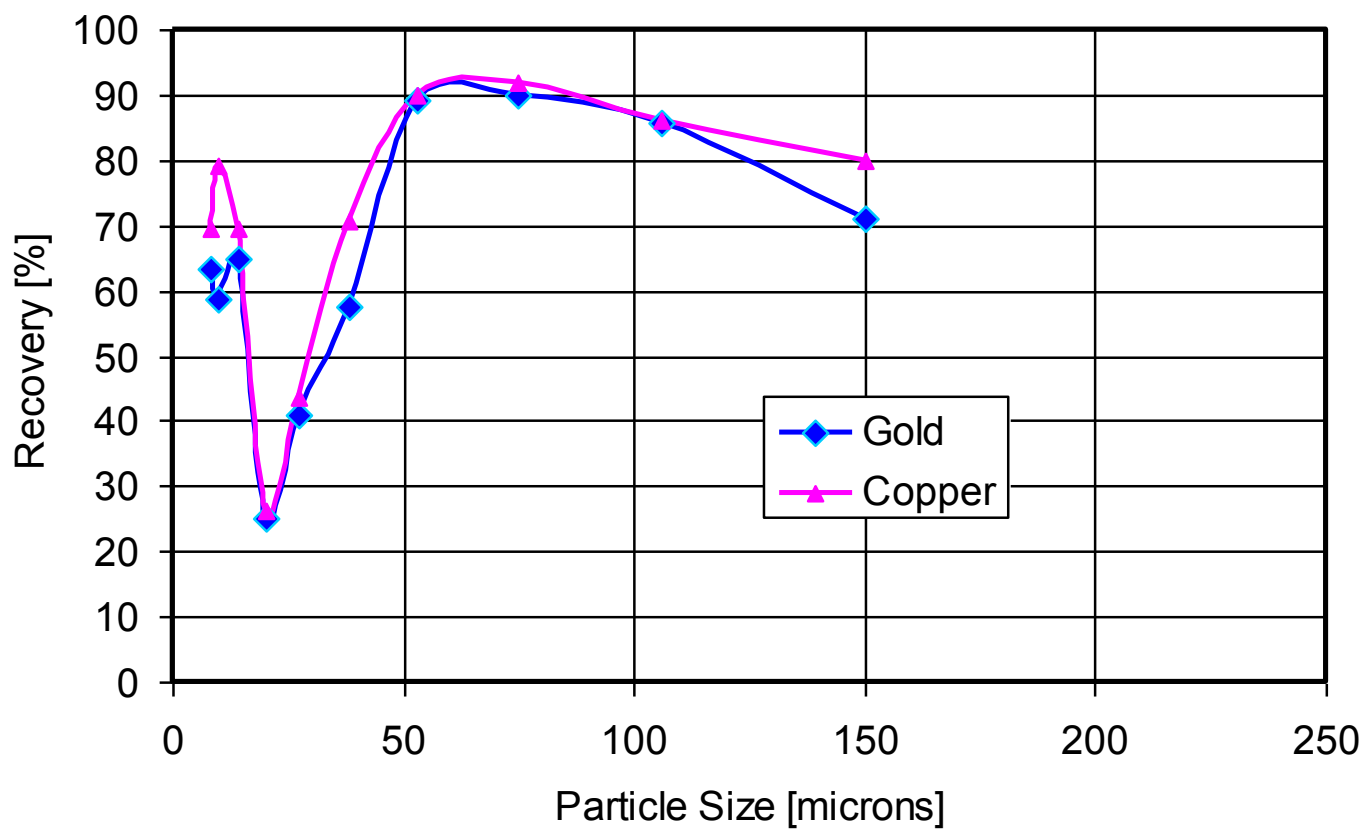

Figure 6: Gold and Copper Recovery for Rougher Cell Number 5

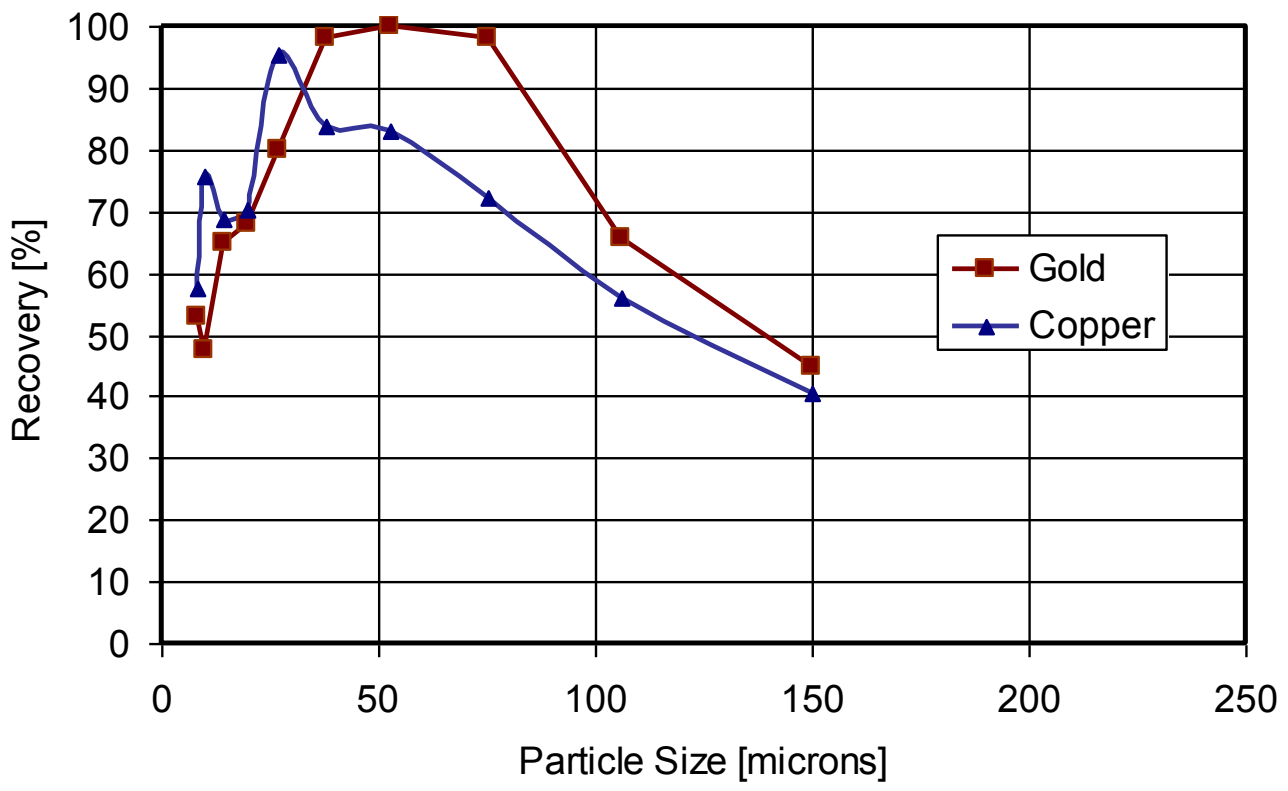

Figure 7: Gold and Copper Recovery for Rougher Cell Number 6 


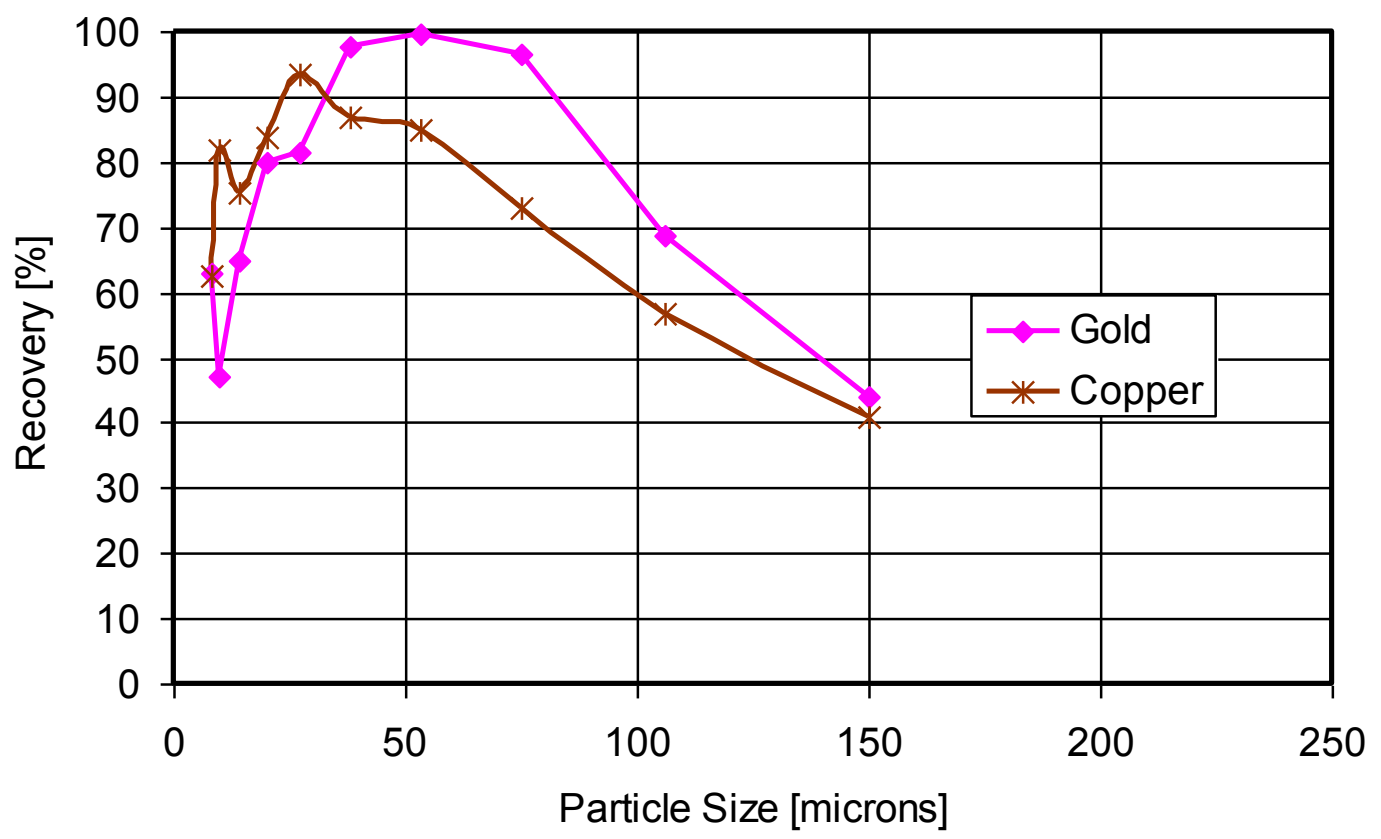

\section{Figure 8: Gold and Copper Recovery for Rougher Cell Number 7}

In the first three rougher cells, there is no clear trend in gold or copper recovery. Their recover fluctuates as the slurry moves from down the rougher circuit. This can be attributed to competition between minerals to float. In sulphide flotation the most hydrophobic or the easiest to float are expected to be recovered first, followed by the flotation of minerals that are more difficult to float (Fuestenau et al., 2007). That, together with the effect of difference in mineral specific gravity and tendency of very fine particles to loose their chemical identity in favor of domination by physical forces tend to combine resulting into the observed fluctuations. In the rougher flotation cell number four an equilibrium of some sort seems to be reached and thus establishing a similar trend in gold and copper recovery that is observed in subsequent cells.

In the last three rougher cells, the trends for gold recovery matches closely with copper recovery. This is what is expected if there is no segregation error which is normally associated with gold sampling or systematic error where introduction of a single small pure gold particle tend to have large effect on calculated recovery (Mular et al, 2002).

\section{Cell by Cell Recovery}

The results obtained can be interpreted with emphasis on the performance of individual cells and how particles of different sizes are recovered on those cells. For clarity, the particle sizes can be classified in three groups, as: coarse particles $(-212$ to $+75 \mu \mathrm{m})$; fine particles $(-75 \mu \mathrm{m}$ to $+20 \mu \mathrm{m})$; and ultra fines $(-20 \mu \mathrm{m})$.

As depicted in Figure 9 almost all gold in $+212 \mu \mathrm{m}$ size particles were recovered in rougher cell number 1, 2 and 3. Although small amounts of these course particles remained in the slurry, there was insignificant recovery in the rest of the rougher cell circuit. This could be attributed to recovery of free gold which despite its size, it is quickly floated out in the first three cells. The remaining course particles are middlings which is made of part gold and part gangue. Within the 
middling there is a conflicting reaction towards the flotation as a result most of these particles remain in the tailings (Personage, 1985, Sotherland, 1955, Bolatovic, 2007). Gold recovery for the particles in size range $-212+150 \mu \mathrm{m}$ was lower in rougher cells number 1,2 , and 3 where the recovery was below $40 \%$ and increased to above $70 \%$ in rougher cells number 4 and 5 and then was decreased to $50 \%$ in rougher cells number 6 and 7 .

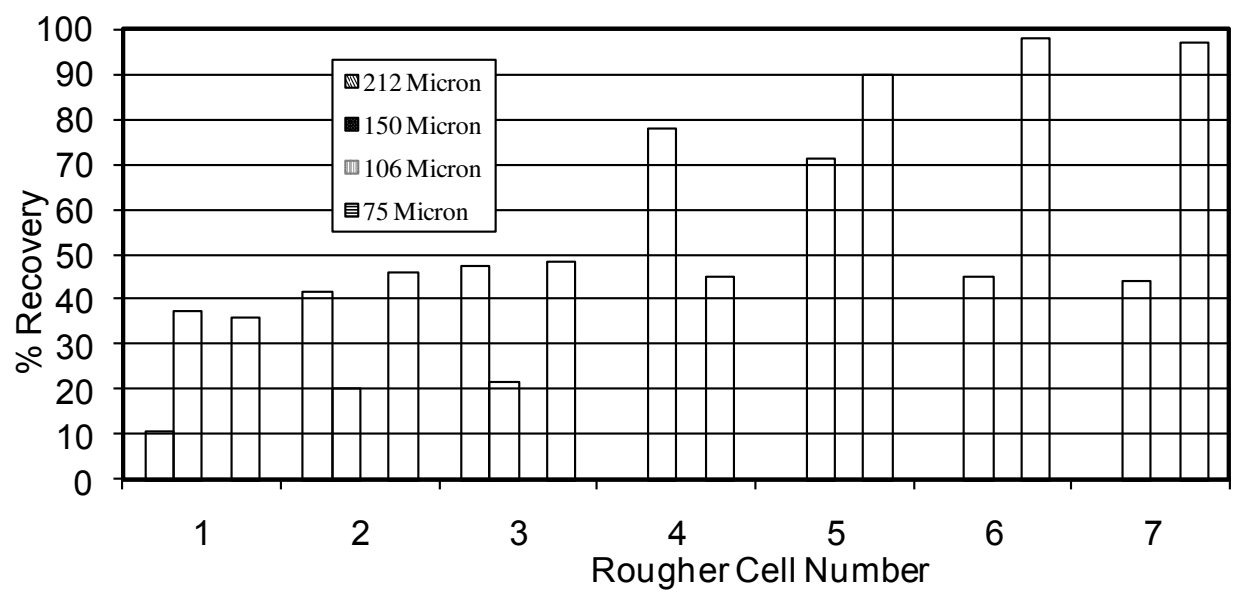

Figure 9: Gold Recoveries for Different Coarse Particle Sizes

Gold recovery for the particles $-150+106$ $\mu \mathrm{m}$ was below $30 \%$ in rougher cells number 2 and 3 but improved significantly to between 65 and $85 \%$ on the rest of the cells. At the same time, gold recovery in the material ranging $106+75 \mu \mathrm{m}$ was low in rougher cell number $1,2,3$, and 4 in which the recovery was below $50 \%$ which the improved to well above $90 \%$ in subsequent rougher cells number 5, 6 and 7. This trend shows that gold was recovered according to size as one moves down the rougher circuit with the largest particle sizes recovered first, followed by next large particle size and so on.

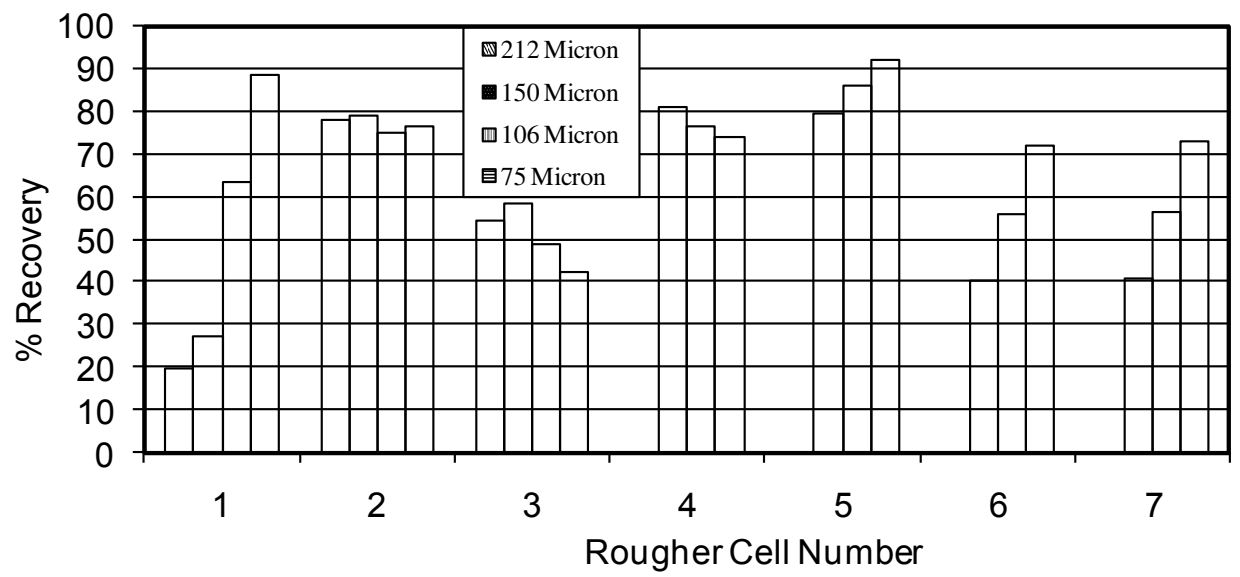

Figure 10: Copper Recoveries for Different Coarse Particle Sizes 
A similar comparison can be made for the copper recovery in the same particle size range. Figure 10 shows copper recovery for $212 \mu \mathrm{m}, 150 \mu \mathrm{m}$, and $106 \mu \mathrm{m}$ and 75 $\mu \mathrm{m}$ sizes in all rougher cells. As with gold, the $+212 \mu \mathrm{m}$ size particles were recovered in rougher cell number 1,2 and 3 only and it was not floated in the rest of the rougher cells. Similarly, in the $212+150 \mu \mathrm{m}$ size range, copper recovery was good in cells number 2,4 and 5 where it ranged between $79 \%$ and $81 \%$, with lower recovery observed in rougher cells number 1, 6 and 7 . The copper recovery in $-150+106 \mu \mathrm{m}$ size particles was higher in rougher cell number 1,2 and 4 where it ranged between $64 \%$ and $86 \%$ and was below $60 \%$ in the rest of the rougher cells. The $-106+75 \mu \mathrm{m}$ size particles were recovered well in all the rougher cells except in rougher cell number 3 and 4, with the highest recovery shown in rougher cell number 5 at $92 \%$.

The recovery of relatively fine particles ranging between 20 and $75 \mu \mathrm{m}$ is graphically shown in Figure 11 . The recovery trend is similar for all the size ranges, with the gold recovery in $-75+53$ $\mu \mathrm{m}$ size range being generally higher than $-53+38 \mu \mathrm{m}$ size range and subsequently decreasing with decreases in particle size in all rougher cells.

Moderate recoveries in these sizes are observed in rougher cell number $1,2,3$, and 4 where recoveries are below $60 \%$. The recovery increases for all the sizes from rougher cell number $5(89 \%, 57 \%$, $41 \%$ and $25 \%$ ) to rougher cell number 7 where they reach $99 \%, 98 \%, 81 \%$ and $80 \%$ for $53 \mu \mathrm{m}, 38 \mu \mathrm{m}, 27.1 \mu \mathrm{m}$ and 20 $\mu \mathrm{m}$ sizes respectively. The 'slimes' effect of the finer particles contribute to the decrease on their flotation efficiency.

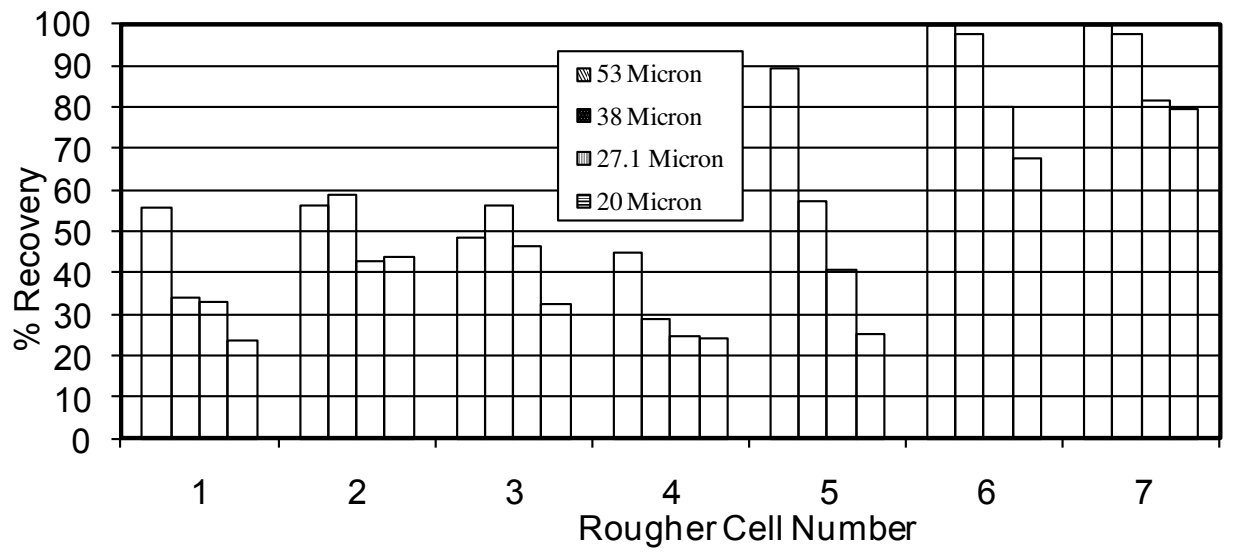

Figure 11: Gold Recoveries for Different Fine Particle Sizes

Copper recovery for the $-75+20 \mu \mathrm{m}$ (Figure 12) shows a slightly different trend compared to gold recovery in the same size range (Figure 11). High recovery was registered in rougher cells number 1, 2, 5, 6 and 7. Relatively large sizes within the rage registered higher copper recoveries of above $85 \%$ in rougher cells number 1,6 and 7 . All particles within this size range were observed to have poor copper recovery of below $48 \%$ in cells number 3 and 4 .

Figure 13 shows gold recovery for very fine sizes below $14.2 \mu \mathrm{m}$. Gold recoveries 
were higher in rougher cells number 2, 5, 6 and 7 although on all sizes they hardly reached $60 \%$. In general the gold recovery in the very fine particle size was poor. This can be attributed to co-flotation of gangue with finer mineral particles thus selectivity decreasing the gold recovery. Copper recovery for the very fine size fractions in different rougher cells is as depicted in Figure 14. Although there is a slight improvement in copper recovery compared with gold recovery, rougher cells number 3 and 4 still had very poor recovery in some cases as low as $23 \%$. Overall the recovery of both metals in the very fine particle sizes was found to be poor due to 'slimes' effects associated with--finer-particles.

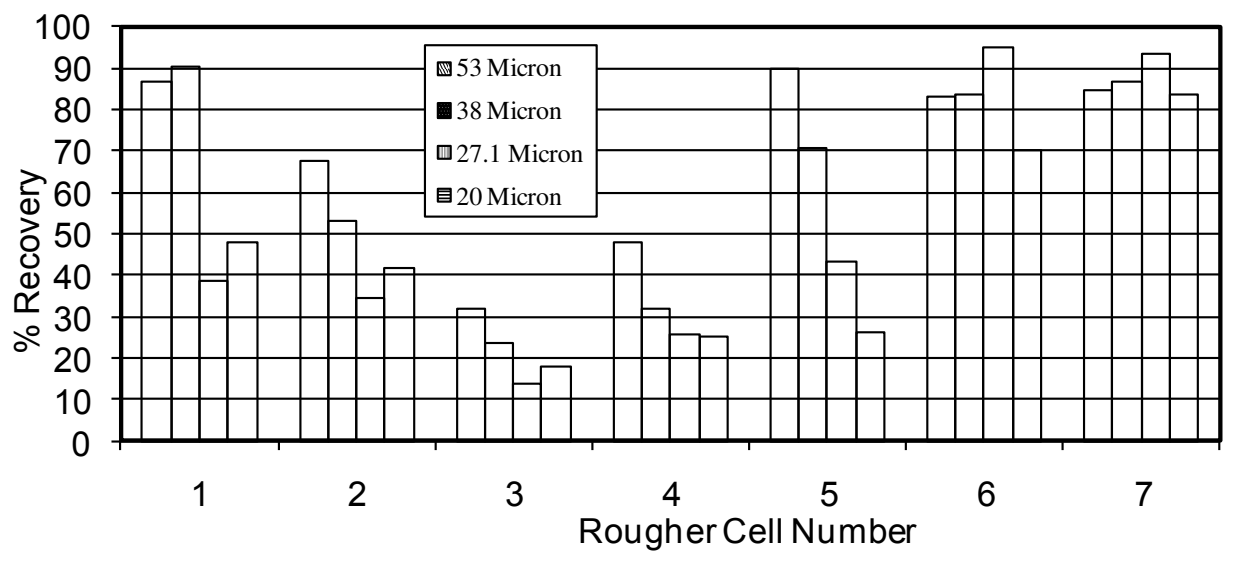

Figure 12: Copper Recoveries for Different Fine Particle Sizes

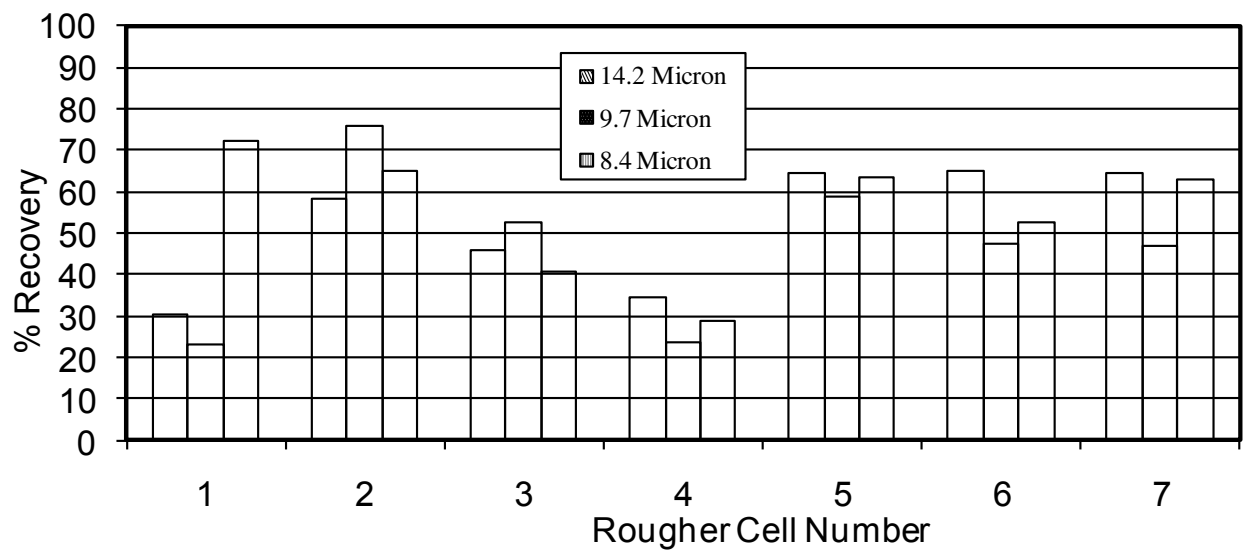

Figure 13: Gold Recoveries for Different Ultra Fine Particle Sizes 


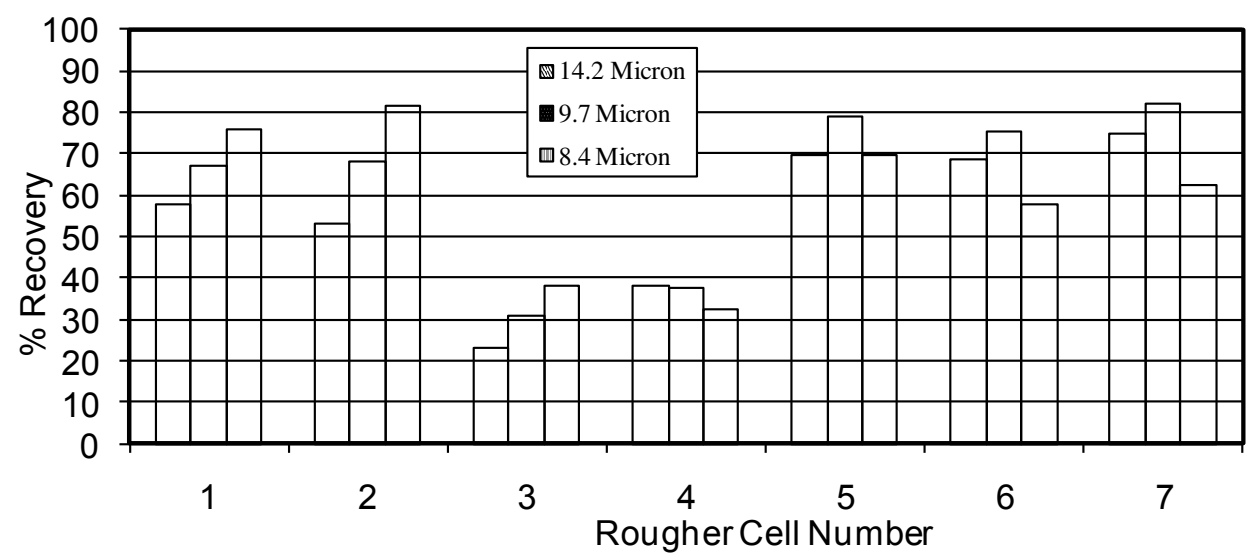

Figure 14: Copper Recoveries for Different Ultra Fine Particle Sizes

\section{CONCLUSION AND RECOMMENDATIONS}

The overall performance of rougher cell number 3 and rougher cell number 4 was poor as they had very low recoveries for both gold and copper especially for the fine particles below $53 \mu \mathrm{m}$. Rougher cells 3 and 4 operating conditions should be be changed to improve their recovery. Rougher 1 gold recover was below 57\% in most of the particle sizes, whereas the last two rougher cells (i.e. number 6 and 7) had good recovery performance for both fine and coarser materials. Good recoveries of gold and copper were obtained in the size range between $53 \mu \mathrm{m}$ and $106 \mu \mathrm{m}$ with the $75 \mu \mathrm{m}$ producing best recovery results, therefore the plant designed grinding size of $80 \%$ passing of $75 \mu \mathrm{m}$ is still viable. Fine particle below $38 \mu \mathrm{m}$ exhibited poor recovery of below $50 \%$ for both gold and copper in most of the cells. The grinding circuit should therefore be operated such that overgrinding to below $53 \mu \mathrm{m}$ is minimized so as to reduce loss of the valuable minerals.

\section{REFERENCES}

Afrane G., Woode M.Y. and Ongunniyi D.S., Mechanical Separation Process, $2^{\text {nd }}$ edition, pp. 187-200, UNESCO Nairobi, 2001.

Basilevsky, A., Statistical Factor Analysis and Related Methods, pp. 160-179, John Wiley \& Sons, New York, 1994.

Bulatovic S.M., Handbook of Flotation Reagent, Vol 1, pp. 87-122, Elsevier, 2007.

Crozer D. D., Flotation, Theory Reagents and Ore Testing, $3^{\text {rd }}$ edition, pp. 25-39, Pergamon Press, New York, 1963.

Fuerstenau M.C., and Han K.N., Principles of Mineral Processing, pp. 245299, Society of Mining, Metallurgy and Exploration Inc., Colorado, USA , 2003

Fuerstenau M.C., Jamesin, G. and Yoon R-H, Froth Flotation- A Century of Innovation, pp. 245-260 , Society of Mining, Metallurgy and Exploration Inc., Colorado, USA, 2007 
Gaudin A. M., Flotation, $2^{\text {nd }}$ edition, pp. Parsonage P.G, Effects of Slime and 182-355, McGraw Hill, New York, 1957.

Colloidal Particulate on the Flotation of

http://www.mine-

enginer.com/mining/assay $2 . \mathrm{htm}$

$(12 / 10 / 2009)$

Sulphide Minerals, pp 55-71., Elsevier, Amsterdam,1985.

Sutherland K.L and Walk, I.W., Principles of Flotation, pp. 25-52,

Mular A.L., Halbe D.N and Barratt D.J., Australian I.M.M. 1955,

Mineral Processing Plant Design, Practise and Control, pp. 1095-1124, Society of Mining, Metallurgy and Exploration Inc., Colorado, USA, 2002.

Wills B. A., Mineral Processing Technology, $6^{\text {th }}$ edition, pp. 258-336, Elsevier, $\quad 1997$. 